\title{
State of Electoral Rights in Conflict Situation: The Case of Manipur, India
}

\author{
L. Muhindro Singh, Ph. D \\ Senior Fellow, ICSSR, New Delhi and Coordinator, Human Rights Studies Centre, S. Kula Women's College, \\ Manipur, India
}

\begin{abstract}
In the backdrop of various conflicts situation electioneering activities are also managing within electoral cycle. How emerging electoral trends maintained electoral integrity and avail electoral rights to the people is a great deal of this analysis. Main focus of the study is to insight the emerging modus operandi of ethnic assertion in electoral politics in the hill areas where even armed opposition groups are often attempted to nominate their nominee who have loyal to them, and how the non-state actors disturb electoral rights? Threaten and intimidation from various quarters disturb the freedom of choice and in turn it develop foundation of flawed democracy. Various factors associated with conflict affects electoral integrity. Significantly such malpractices are becoming a normal practice in many developing democratic countries and exacerbating in this tiny multi ethnic and cultural state. As such, a quantitative and empirical method is employed to insight the quantum of electoral integrity. All the analysis and theory-building is based on quantitative data collected from electorates of entire Manipur. But many electorates and stakeholders have still hiding their faults; instead it is seemingly considering a new culture of electoral mosaic.
\end{abstract}

Keywords: electoral integrity, ethnic assertion, conflict, threat, intimidation

\section{Introduction}

The goal of elections is to have an open competitive to the eligible citizens, aspirant candidates and electorates to exercise their rights for installing a government of the people for the people. Democracy largely depends on the level of electoral system and its participation. ${ }^{1}$ Those scholars who dealt with the democracy felt to appreciate the quality of new democracies around the world, and considered the changing pattern of mass participation. ${ }^{2}$ If the result of the elections can't reflect accurately the will of the electorates, the process and the outcome will demean democracy and eventually develop flawed democracy. See the experience of Manipur where ethnic assertion on electoral politics is dominating in contemporary in the hill areas. Non-state actors have been trying to insert their infiltrators in the lawmaking bodies with certain perspective. No one will deny Manipur has dual governance of constitutional and non-constitutional and more powerful by non-constitutional one which is long experience of Manipur. In contemporary, many armed opposition groups have been entering in electoral politics and politicians have nexus with them for mutual benefit. Such trends are seemingly very noticeable phenomena of electoral politics in the sense that both the central and state government are also somehow managed it and claimed free and fair elections. They often made attempt to nominate their candidates who have loyal to them, eventually such coercive influence violate electoral rights of those aspirant candidate. And also even create an unusual social chaos where people reluctant to express their freedom of thought. Ethnic Civil organisations and frontal organisation supported by armed outfits are also actively involved in electoral politics in the hill areas with certain objective. On the other hand, the dynamics of ethnic assertion on the eve of elections in the valley area is quite different that such ethnic influences are very low. Various factors associated with ethnic conflict sometimes affect electoral integrity. In such conflict areas 'bullying' is one of the most common factors on the eve of election. In contemporary electoral rights are often violated on the eve of elections. Different acts of state and non-state actors have been threatening human rights. The United Naga Council (UNC) in the State made clear that they would like to be part of a Greater Nagaland as demanded by the NSCN-IM and strongly involved in the electoral politics since NSCN-IM entered in political dialogue with Government of India. No one will believe it the act of one national party, issuing threats to prevent the potential contestant from participating in the electoral process. ${ }^{3}$ In the political conference organized by the Nambol Block Congress committee (NBCC) at the Nambol AC on 12 January 2007 resolved to socially ostracise any person belonging to the Leimapokpam Gram Panchayat (GP) Area who attempts to contest the $9^{\text {th }}$ Assembly and also not to allow any form of election canvassing in the said area. One of its resolutions stated that if any resident of the area within the jurisdiction of the Leimapokpam GP area files nomination or campaign for any party other than the INC, they would be thrown out of locality. ${ }^{4}$ 


\section{Electoral Integrity: Concept}

In this study the core concept of electoral integrity, which is understood as shared international principles, values, and standards of democratic elections which apply universally to all countries and which should be reflected at all stages during the electoral cycle, including the pre-electoral period, the campaign, polling day and its aftermath. Violations of electoral integrity, by contrast, constitute electoral malpractices. ${ }^{5}$ For conducting free and fair elections, the concerned authority provided does and don'ts in their Respective Representation of People Acts and Model Code of Conduct, but many political parties, candidates and connivances have often committed illegal acts on the eve of elections, all these are malpractices. For instance, different party leaders overtly and covertly made attempt to woo / lure peoples in the name of collective goods or for particular backward community. The issue of election fraud is found in many developed democratic countries. 'After the 2004 presidential election, many Democrats went on the warpath over alleged voter fraud and manipulation in Ohio and elsewhere. ${ }^{6}$ It is also witnessed that ruling party or incumbent government party have often been misused their power. It is therefore important to understand the nature of these challenges and what can be done to avoid these problems which is inclusive elements of electoral integrity. The notion of 'electoral integrity' is gaining in popular usage as an all-encompassing way to conceptualize many related problems. ${ }^{7}$

\section{Political Party On Ethnic Line}

Obviously, ethnic political party is not yet emerged in the valley though some hill based political party have much vocal on the ethnic line for their political gain but not so success. The KNA (Kuki National Assembly) ${ }^{8}$ was one of the earliest political parties which emerged in the hills of Manipur that raised the grievances of the hill people and actively participated in the electoral politics ${ }^{9}$ though it was seemingly extinct in contemporary. The party stands for preserving and improving the culture of the Kukis, freedom from external exploitation and unification of their geographical areas into a political unity. ${ }^{10}$ It became the mouthpiece of the non-Naga Hill Tribes in Manipur demanding a Kuki state within the framework of Indian federation in 1960, and later on further relaxed its stand by demanding a full-fledged revenue district for the Kukis in the face of stiff Naga resistance. ${ }^{11}$ Another ethnic political party, Naga National Party (NNP) emerged from a sense of disillusionment on the part of certain sections of the Nagas due to the absence of effective and accountable government inside the state for a long time and not given proper attention to the genuine voices of the Nagas. ${ }^{12}$ It was also a party that promised to work as a political platform for all the Naga people in the North East region. ${ }^{13}$ The party aims to promote emotional integration and unity, and build up the spirit of oneness amongst all Nagas; to help in bringing a lasting and peaceful political solution to the age-old Naga political issue through dialogue; and to maintain Naga identity in letter and spirit. ${ }^{14}$ Significantly, in the recent years Ngaland based ethnic political party NPF (Naga People's Front) was on the scene of electoral politics on the eve of Manipur State Assembly Elections 2012. Since then many people drew attention on such new phenomena of ethnic politics in the hill area where even the Nagaland Chief Minister Neiphiu Rio campaigned and ethnic assertion was more vocal. ${ }^{15}$ From various quarters, it is observed that the NPF is working with the support of one Naga insurgent group which is also evident from various appearance and allegations. (NPF operated and governed in neighbouring state Nagaland which is also popularly known for NSCN-IM's support) Nonetheless some new strategy was also found in the hill areas that earlier NSCN-IM put up there candidate as 'Independent' but in this State Assembly Elections 2012 nominated 12 candidates through Naga People's Front. The UNC calling on the Nagas to support the Naga People's Front, making its debut here in Manipur with the stated aim of uniting the Naga inhabited area under one administrative roof. ${ }^{16}$

\section{Emerging Electoral Trend On Ethnicity}

Elections in the remote hill areas are not free and fair. Most of the officials who engaged in the election in the hill areas opined that, 'they cannot perform the electoral norms what the election commission instructed due to various factors, of them secure life is most important, so conditionally they have to compromise in a manageable way'. ${ }^{17}$ In general, if one employee is bound to serve election duty in the hill area, first and foremost conception and priority was "alternative means if possible'. Many political workers or protagonist in the particular polling area have often been acted as authority and committed different coercive activities in favour of particular candidate. Election officials and security forces seem to have no power in such circumstances that they cannot interfere to the unfair means in election. Interestingly, so far, none of the electorates made complained in regards to their electoral right. It is true that government machineries in the hill areas cannot work properly as there is dual governance of state and non state actors. Most of the top brash officials posted here need to develop a cordial nexus with dominant non-state actor. Various incidents and appearance witness the nexus with Deputy Collector of the districts and armed opposition groups. Otherwise, they have to bear dire consequence like killing, torture, and kidnap. Indeed most of the electorates cannot do against the will of the armed opposition groups and its frontal organisations. 
On the other, with the changing scenario of electoral behaviour, not only in the hill but also in the valley, most of the politicians turn into unethical politics. That most of the candidate has their own illicit forces and made various activities that spread psycho-fear amongst the electorates. It may be noted that MLA Ng. Kumarjit Singh of MPP stated in the Manipur Legislative Assembly Session, 'Politicians have to stop the culture of using youths by supplying armed ammunition and harassing the people for some political benefit on the eve of election. Politics should be done sincerely and genuinely. ${ }^{, 18}$ Obviously, elections in hill and remote areas are witnessing abnormal election where many electorates could not enjoy electoral rights. Not only electorates, candidates too have been facing threaten from various quarters. Moreover some ethnic civil organization who have loyal to armed opposition groups have been acting like a political party and imposed does and don't to the electorates and candidates. In such areas political elites have nexus with insurgents and using them for mutual benefit. (Marwah 2010) Perhaps the conflict situation may compel to do so. Politics in the Northeast are not based on democratic norms as understood in the western-model democratic system. As money is the name of the game, most political leaders find it convenient to develop close associations with one insurgent group or the other. (Ibid)

During elections political leaders seek support of the insurgents in the form of muscle power. They also depend on them for emotional appeal to the electorate on ethnic lines. In lieu of their support, they share part of the loot from public funds with them and intervene with the state police in their favour. This in turn has led to a breed of greedy political leaders whose main interest in politics is to make money and not serve the people. The entire political system in the region has grown around these unscrupulous politicians. ${ }^{19}$

\section{Quantum Of Electoral Integrity In Manipur}

With this new concept of electoral integrity it is trying to accentuate the electioneering context of Manipur. The main focuses were how the electorates enjoy their franchise; whether they are facing dilemma or threat from any quarters; how the malpractices are underwent on the eve of election; in general how the people assumed the prevailing trend of electoral politics in this conflict state? Most significantly, it is to insight the emerging modus operandi of ethnic assertion in electoral politics in the hill areas where even armed opposition groups are often attempted to nominate their nominee who have loyal to them, and how the non-state actors disturb electoral rights?

Not a single method cannot fulfil the expected result is agreeable. For more accuracy, quantitative, qualitative, empirical methods are primary tools adopted here. Sources of data were mainly from structured questionnaire collected from electorates of entire Manipur. But many electorates and stakeholders have still hiding their faults; instead it is seemingly developed a new culture of electoral mosaic. Logically, intimidation and threat may have certain impact on the freedom of choice but it is very doubt as the finding shows relatively different from assumption and witnesses. Altogether 140 samples are collected from all the 9 districts, of which Chandel 13; Senapati 12; Thoubal 15; Imphal East 18; Imphal West 31; Churachandpur 12; Bishnupur 10; and Tamenglong 18 made the population and universe of the study.

\subsection{Malpractices on the elections}

a) Freedom of choice

In contemporary, malpractices are very great deal to all the electoral studies, but attempts to find out an acceptable argument is not an easy task that almost all the malpractices are multifaceted and seemingly claimed as acceptable in one or either form. For instance, election code of conduct and other relevant laws of the state are being instructed to maintain certain rules, but candidates and workers have often indulged in illicit activities. It is also very unfortunate that none of us have serious for freedom of choice instead it is being treated as electoral politics. Majority of the respondents 71 percent agreed that illegal practices on the eve of elections disturb freedom of choice while 15 percent support the view partially.

b) Dole for vote

In one or other form, corruption may be come up on the eve of election despite electoral laws said that ${ }^{20}$ "any gift, offer or promise by a candidate or his agent or by any other person with the consent of a candidate, or his election agent of any gratification, to any person whomsoever, with the object, directly or indirectly of inducing to make certain changes willingly or unwillingly to fulfil the connivance or perpetrators." On the other hand, dole for vote became a serious issue in elections, whether it may be in different modus operandi like distribution of goods, cash or even promise to gratify particular electorates or family just after election. As both the counterparts giver and taker have involved and liable to be punished, the possibility to prove genuinely is very doubtful. But it is cleared that more than two-third of candidates have often been attempted to lure electorates by unfair means. See the following figure (no some of them $31 \%+$ yes all of them $58 \%=89 \%$ ) 


\section{Table 1:}

Most of the candidates have always in misconception and committed politics of destruction. On the other hand, majority of electorates were also on the whims in the sense that they have readily accepted the odds. That 85 percent of electorates were aware of such dole for vote besides, 13 percent support with positive view thought they can't say out-rightly which meant many of them might be in the net of this malpractice.

Table 2:

c)

Way of transit

When it enquires whereabouts the information for dole for vote came in to the electorates, $53.6 \%$ respondents hinted that they got information from the agents/friends while those who said 'eye witness' of dole for vote was $23.6 \%$. Very unexpectedly, information obtained from spouse was very low with just $8.6 \%$, despite it claimed $13.6 \%$ from family or relatives. Thus the analysis confirmed that such malpractices are mainly carried out through election agents/workers.

\section{d) Quantum of influence}

Table 3:

Significantly, how far it can influence the electorates will be very remarkable since $38 \%$ respondents positively said it might be influenced by justifying what they got more. $21 \%$ respondents denied that it cannot influence and the argument was also supported by another $21 \%$ on the line that 'to whom vote for' was already decided so influence by dole for vote may not be possible. On the other hand, some of the respondent $18 \%$ have suspicion of such influence but cannot say. So it is very dubious that $56 \%$ viewed possibility of influence while $42 \%$ denied it.

e) Threat to party or candidate

Table 4:

$\mathrm{AB}$ Bardhan, as observer of CPI had expressed apprehension that the ensuing elections might not be held in a free and fair manner in view of opposition and diktat by underground groups on various candidates in both the hills and valley areas. As a National Secretary of CPI, he came to oversee the Election Campaign of the party in the state as observer. ${ }^{21}$ Four independent candidates of 47 Karong AC have cried foul allegedly over the involvement of some NSCN-IM men including upper rung leaders in the election campaign for improving the prospects of UNC sponsored candidate, RV Shirang. ${ }^{22}$ NSCN-K bans all candidates in Tamenglong AC as it felt that the NSCN-IM had grossly manoeuvred the process to ensure the election of the candidate put up by them. ${ }^{23}$ In the third and final phase elections, three candidates have taken forced retirement. ${ }^{24}$ Those who have taken Forced retirement included one independent candidate of Tamenglong AC, and two CPI candidates at Tengnoupal and Chandel AC. The retirement of two CPI candidates came after an independent candidate; $\mathrm{Mr}$. Khangthuanang Panmei was abducted from his residence in Tamenglong Headquarters in 17 February 2007 in the last couple of days preceding polls. The outfit alleged him of "lending support to the anti-UNC Policies of the so called peace rally." 25 Two CPI candidates, Onzamang Haokip of Tengnoupal AC and Nehkhothang of Chandel AC have taken forced retirement as they were threatened of dire consequences by some insurgent groups even as the repeated appeals of the village elders to allow free and fair election went unheeded. ${ }^{26}$

Threats or intimidations to follow their (armed opposition groups AOP) diktat to the particular candidates or party are not an exception in this state. It is witnessed by various reported news and appearances: National Congress (INC) has alleged the Naga People's Front (NPF) of using insurgents /armed opposition groups (AOG) in their favour and resorting to all sorts of election related crimes in the recently held Manipur state assembly elections 2012. ${ }^{27}$ The Kuki militant groups, which are under Suspension of Operations (SoO), and the NSCN-IM, which is also under peace-talks with the Centre were openly involved elections. The Kuki militants openly supported the INC candidates, while Naga People's Front (NPF) was supported by the NSCNIM. Involvement of the AOG in the election and threaten electorates and challenges to electoral rights is no doubt will remain so long is proved by the existence. ${ }^{28}$ A conglomeration of valley AOGs in the valley, CorCom (the Coordinating Committee consisting of different armed groups like KCP, KYKL, PREPAK, PREPAK (Pro), RPF, UNLF and UPPK.) targeted to defeat INC. ${ }^{29}$ Admitting the involvement of NSCN-IM in election matter, Home Minister P. Chidambaram said NSCN-IM is in talks with the Government of India. It is also true that NSCN-IM cadres along with some other organisations continue to indulge in kidnapping and some time violence. $^{30}$ The finding shows that most of the threats are coming up from armed opposition groups which meant 50 percent respondent hinted though 18 percent kept mum due to psycho fear. Besides, state-actors who are ought to protect electoral rights are also amongst the perpetrators. 
Bullying to electorates

Table 5:

Bullying or intimidations on particular elector or electorates were also aplenty on the eve of elections. The modus operandi of intimidation might be any act of bullying or coercive force to make behavioural change of electors, for instance, intimidation to support or not to support particular candidate or party, or not to involve in any electioneering activities which is attempt to curve freedom of electorates. In short, it is violation of electors' right who is supposedly to enjoy freedom of choice to exercise their conscience and wisdom to elect the worthy candidate. Such intimidations often appear in many parts of Manipur though the frequency is accordingly different. For instance, after banning the INC indefinitely and issuing warnings against INC workers to desist from election related works, the CorCom launched a series of bomb attacks on INC offices and residence of workers. ${ }^{31}$ Trinamul Congress president Kim Gangte said 'Voters in the hill districts failed to get their franchise ... had been paralyzed and manipulated by militants'. ${ }^{32}$ One executive member of Senapati District Congress Committee was severely assaulted by NSCN-IM on 26 January 2012. Amidst the threat of NSCN-IM, a peace rally was staged at Chandel on 19 February by womenfolk demanding that they be given the freedom to freely exercise their franchise without threat and intimidations. ${ }^{33}$ Naga National Council (NNC) charged the Isaac Muivah leadership of shrieking their responsibility owed to the "Naga Nation." It alleged that the formation of UNDF was at the behest of NSCN-IM. It also alleged that the Nagas in Manipur are not only forced and threatened to vote for the UNDF candidate but the IM leaders have also been abducting public leaders from Tamenglong and Ukhrul district areas for raising objections to the NSCN-IM Stances. ${ }^{34}$

Table 6:

The finding shows that, unexpectedly valley area has suffered most on such bullying issue. Imphal west district found more affected by threat to electorates that 11 percent out of 58 percent opined they have noticed such bullying on electorates while 6 percent out of 24 percent supported the argument that they projected as saying 'might be but cannot say'. Significantly, none of the districts are beyond this issues in the sense that the other districts except Imphal east were also within the range of 5 to 6 out of 58 percent who had aware threaten on electorates. More or less bullying on electorates is cleared.

\section{g) Coercive influence by threat}

It is not an easy task to find out the reason for behavioural change by assuming only by threat of coercive influence. The crux of this issue in many of us is how 'coercive influence' will be possible that elections are confidential. No one has the right to violate such personal secrecy. Such appearances of threat, intimidations are mostly found in armed conflict states or naxalite affected states of India but it doesn't claim free from other states. For instance, the proscribed Revolutionary Peoples Front (RPF) chairman in its message categorically rejected the election under "Indian dispensation as a shamble and colonial trap intended to befool the international community" and "denounced participation and involvement of revolutionaries in the election stating that it only leads to lost conviction and diminishing moral strength and provides further stimulus to the colonial state. ${ }^{35}$ The RPF had as usual earlier imposed ban on contesting 2007 election by any of its exmember and ex-cadre of its armed outfit, Peoples Liberation Army (PLA). ${ }^{36}$ The study found, many respondents believed that such diktat may be somewhat influenced to decide their votes in the sense that $47 \%$ respondents favoured on this argument. On the other hand, $27 \%$ respondents opined it cannot influence as since voting is confidential, while $9 \%$ respondents argued that threat or intimidation can be influenced. Besides, mention may be made that, though the AOG threaten to INC, the party got absolute majority in the recent Manipur state assembly elections 2012. It is very contradictory in between the data found and people's assumptions. As per data given below it has strongly supported that $64 \%$ (somewhat influence + fully influence) believed on influence factor while the election result proved uninfluenced.

\section{Table 7:}

\section{Concluding Remark}

Thus, from the above analysis and findings shows that the state of democracy in Manipur is clear example of flawed democracy where elections are totally in servitude. Electorates of this state cannot decide their franchise instead influenced by various factors. Indeed, real democracy is unthinkable without respecting electoral integrity within a viable political party system. In an ideal setting, political parties, political elites and for-runners should not indulge in immoral and unethical politics though it is not an easy task where politics is always associated with power game. Violation or external control to rights, whether it may be in civil, political, and economic rights is unacceptable from the legal or moral point of view. Indeed, all these malpractices are against the electoral integrity that eventually destroys democratic value. The human rights that guarantee everyone a comprehensive legal protection and an equal opportunity to pursue her private life-plans clearly have an intrinsic value. In an ideal setting, political parties basically are expected to serve as a formidable 
democratizing force by articulating and aggregating public opinion and interests, engendering popular participation, and promoting political education and national integration. ${ }^{37}$ For bringing electoral integrity we should encourage various suggestions recommended by those concern organisations, institutes looking forward for internationally agreed standards of electioneering processes. Most of the organisations have sought to expand the capacity and professional standards of independent election management bodies (EMBs). Elections are large-scale, complex and sensitive operations and EMBS need the capacity to develop strategic and operational plans; to assess election costs and prepare budgets; to improve voter registration processes; to implement procurement plans, and to managing the vote count.

\section{Acknowledgement}

I acknowledge my humble gratitude to the authority of ICSSR New Delhi for giving me an opportunity to discuss the issue of Electoral Integrity under the Senior Fellowship Grant. I also extend my thanks to Prof. Pippa Norris, Sydney University, president International Political Science Association, USA and project coordinator "Electoral Integrity Project" who inspired me a lot on the concern area of study.

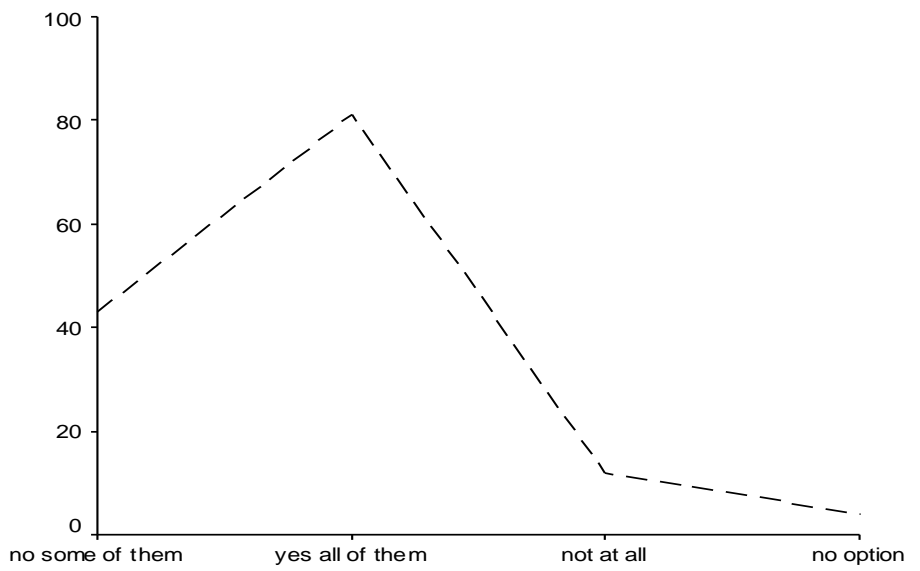

Table 1: Whether all the candidates in your constituency involved in dole for vote?

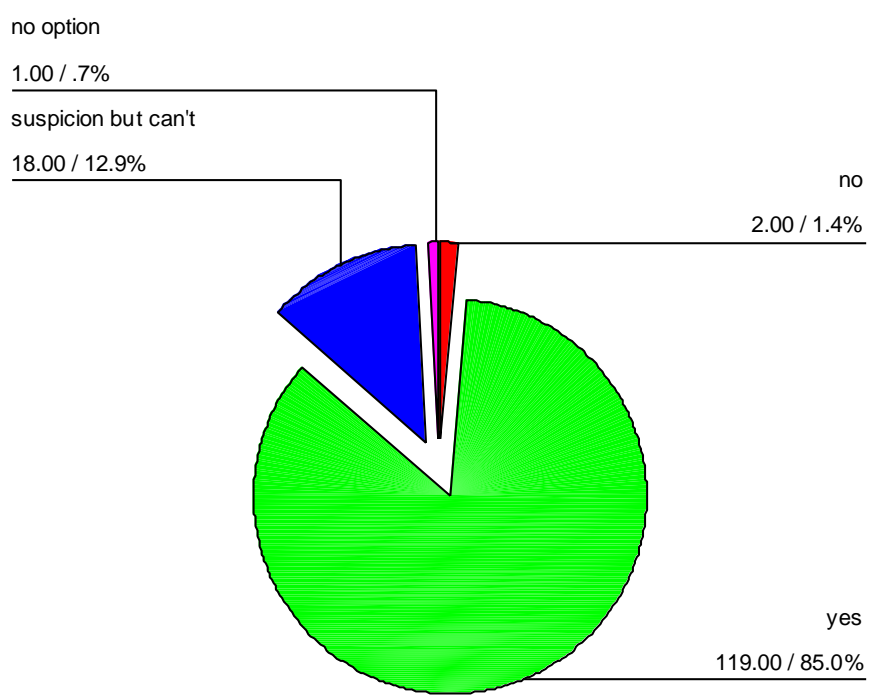

Table 2: Have you heard distribution of case or goods on the eve of election? 


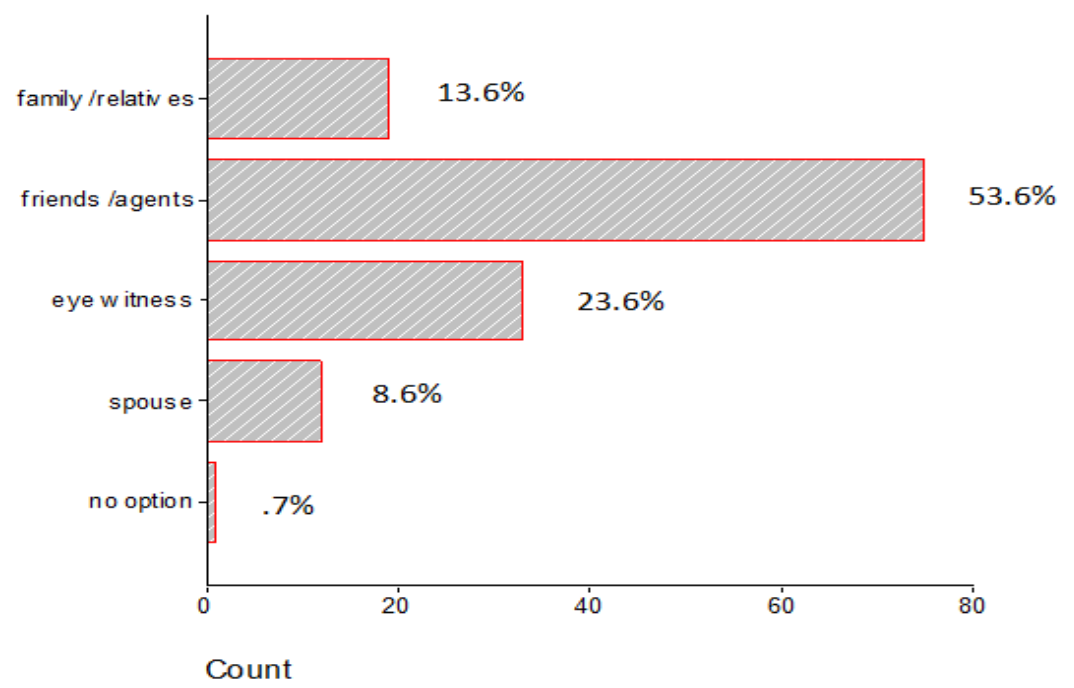

Table 3: From whom you got information for dole for vote?

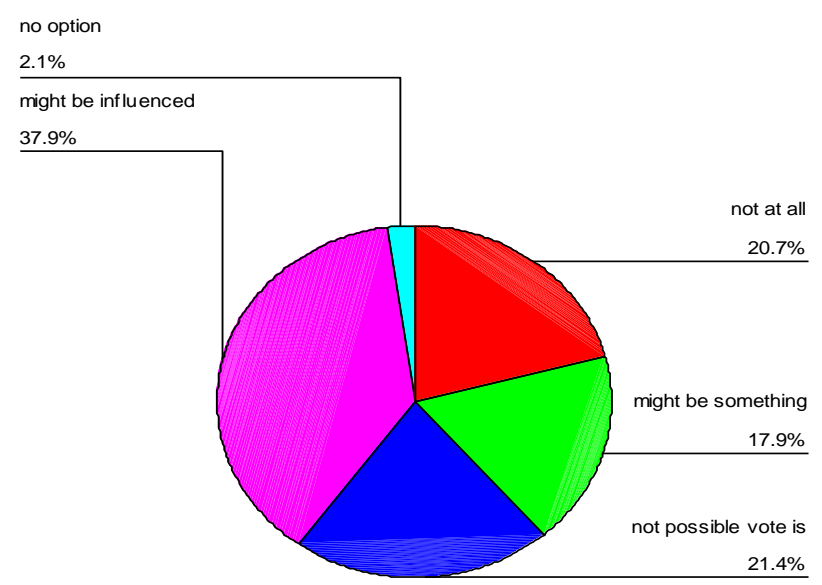

Table 4: Can you say, such dole for vote might have influence on voting?

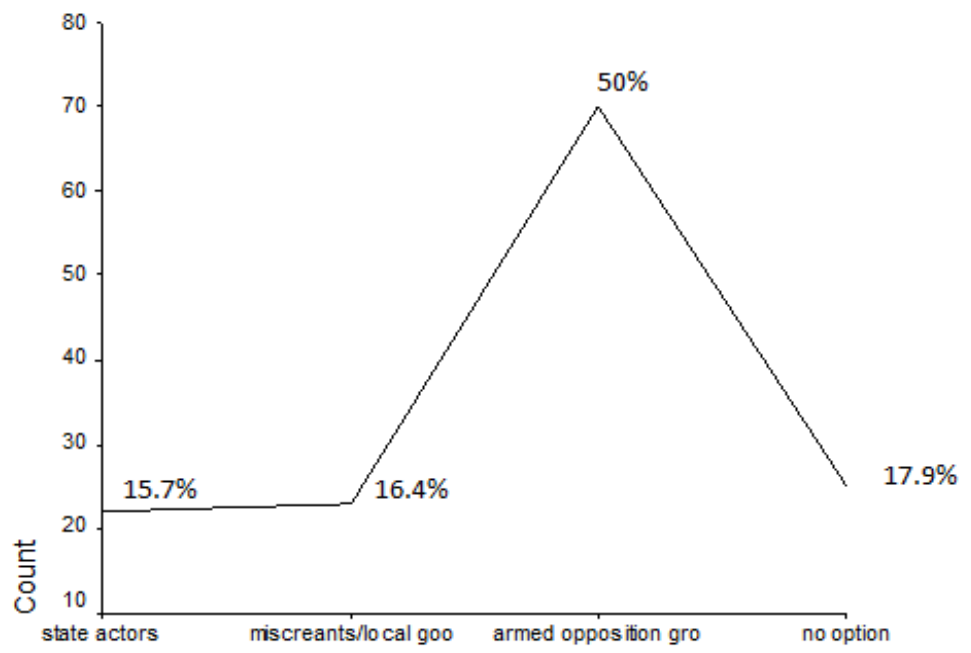

Table 5: Did you hear intimidation / threat to party or candidate from any quarter? 


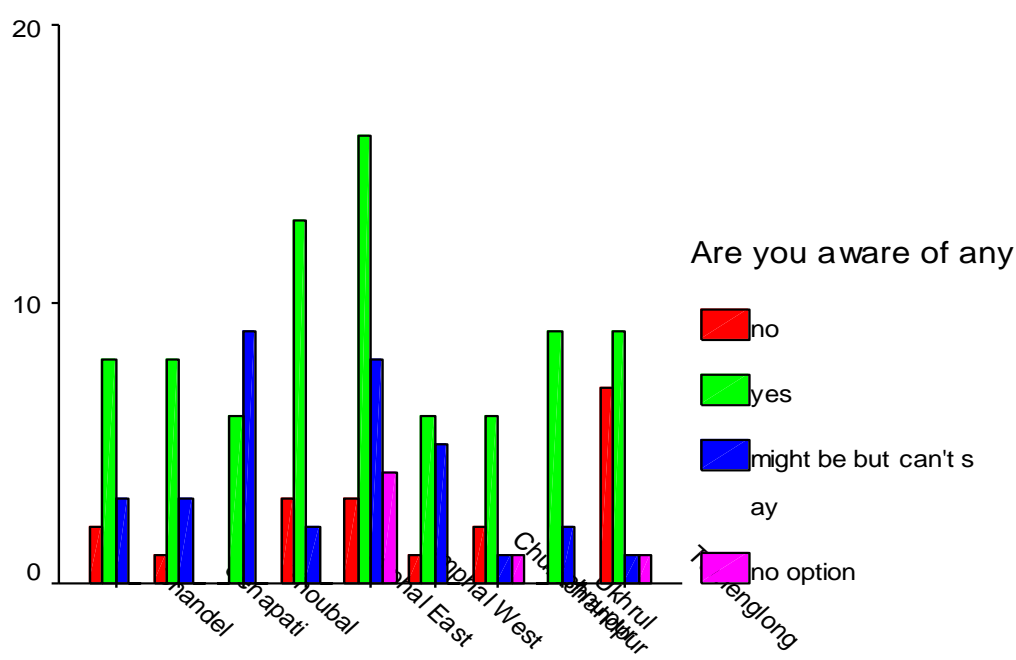

Table 6: Are you aware of any threat to support or not to support particular candidate / party? Cross tabulation

\begin{tabular}{rrrrrr}
\hline & Frequency & Percent & Valid Percent & $\begin{array}{r}\text { Cumulative } \\
\text { Percent }\end{array}$ \\
\hline Valid & can't influence & 38 & 27.1 & 27.1 & 27.1 \\
& somewhat & 66 & 47.1 & 47.1 & 74.3 \\
influence & & & & 82.9 \\
& fully influence & 12 & 8.6 & 8.6 & 98.6 \\
& & & 15.7 & 1.4 & 100.0 \\
can't say & 22 & 15.7 & 100.0 & \\
no option & 2 & 100.0 & & \\
Total & 140 & & & & \\
\hline
\end{tabular}

Table 7: Elections are confidential how far threat can influence voters?

\section{References}

[1]. Lijphart, A., Patterns of Democracy. Government Forms and Performance in Thirty-six countries, New Haven, CT: Yale University Press, 1999

[2]. Michael Bratton; Yun-han Chu and Marta Lagos, 'Who Votes? Implications for New Democracies', Taiwan Journal of Democracy, July 2010, Volume 6, No. 1, pp. 107-136

[3]. Koireng, Aheibam, In the Whirlpool of Delhi Bandits Skulduggery and Insurgency: Manipur Electoral Politics. Paper presented on two National Seminar on Emerging Electoral Trends and Violation of Human Rights: A Paradigm of Exacerbating India's Democracy, 25 - 26 November 2011 at S. Kula Women's College, Nambol, Manipur

[4]. The Imphal Free Press, English local daily vernacular, 13 January 2007

[5]. Pippa Norris, Are there global norms and universal standards of electoral integrity and malpractice? Comparing public and expert perceptions, Perceptions of electoral integrity, Draft 1.0 6/1/2012, (Online) available at: www.electoralintegrityproject.com, accessed on 23 February 2012

[6]. James Bovard, (2005) Attention Deficit Democracy, Palgrave Macmillan, New York, p. 23

[7]. See, for example, the Global Commission on Elections, Democracy and Security launched by the International Institute for Electoral Assistance (International IDEA) and the Kofi Annan Foundation in March 2011.

[8]. Interview with T. Kipgen, the founding secretary of the KNA, Imphal, 13 October 2002, (Thus the Kuki National Assembly started as a socio-political organisation of the Kukis on October 24, 1946 at the Kuki Cooperative Society building in Imphal) in Basanta, A. Sharma, The emergence and the working of MPP and KNA in Manipur: a comparative study, unpublished Ph. D thesis, dept. of Political Science, Manipur University, 2003, p. 111 (Thus the Kuki National Assembly started as a socio-political organisation of the Kukis on October 24, 1946 at the Kuki Cooperative Society building in Imphal)

[9]. All Kuki National Council meeting, Resolution No. 1, held at Tujang village on Aug. 19, 1947.

[10]. Roy, A.K., 'KNA and the electoral politics in Manipur', in Dutta P.S (ed.) Electoral politics in North East India, Guwahati, Assam: Omsons Publications, p. 67, 1986

[11]. Ibid.

[12]. Naga National Party (NNP) manifesto, $8^{\text {th }}$ Manipur State Legislative assembly Elections, 2002, p. 1.

[13]. Ibid

[14]. Ibid. 
[15]. Besides, Nagaland chief minister Neiphiu Rio in his election rally in Tamenglong district had stated that NPF MLAs would bring up the Naga issue in the Manipur Legislative Assembly. Staff reporter, 'O Joy cautions Rio to desist dragging integrity issue into polls', Sangai Express, Imphal, 17 January 2012

[16]. Imphal Free Press under the caption of Choose with prudence, Reported on 26 January 2012 that 'Few days back, suspected NSCN-IM cadres reportedly tried to abduct the President of the Nungba Block Congress Committee and in the ensuing clashes and firing 3 Congress workers were injured.'

[17]. What we experiencing electoral activities in the remote and hill areas the writer interviewed with various official who discharged election duty in the hill areas, one of them Baleshor, U. (who engaged in the election duty in the hill area, 2007) said that they have no option even the security forces cannot interfered on the activities carried out by armed miscreants, perhaps they might have to support particular candidate in such areas. Sometimes they voted as representative of all the electorates. July 7, 2008

[18]. It is very unfortunate those electoral scenes not only in the hill but also in the valley area have been dominating a culture of coercive and threat. Besides, many candidates have their own private army, it is very dangerous in the electoral politics that in politics the concept of 'might is right' becoming common phenomena. In this regard it is worth to mention that ruling party MLA $\mathrm{Ng}$. Kumarjit drew attention all the members of the House to far away from this predicament culture. Assembly proceeding, Manipur Legislative Assembly, Government of Manipur, July 22, 1991

[19]. The growing nexus between the undergrounds and the over ground political leaders and the civil servants is directly related to the lure for easy money. As the people do not trust the state police to protect them, the different ethnic groups have organized their own armed militias. They need funds to maintain these armed, which they secure by extortion and pilferage of government funds practiced on large scale. Ved Marwah, Former Governor, Manipur and Jharkhand delivered a lecture on Ethno-Political situation in India's Northeast, at Centre for Strategic Analysis, Tamilnadu, 19 May 2010

[20]. The Representation of the People Act 1958 Act 14/1958 (Mauritius), sec. 59 and of the Representation of the People Act, 1951 (India) Section 123(1)

[21]. The Imphal Free Press, English local daily vernacular, 22 January 2007

[22]. The Sangai Express, English local daily vernacular, 5 February200

[23]. The Sangai Express, English local daily vernacular, 21 February 2007

[24]. But their names continue to include in the Ballot as there were no official cognizance of such candidates who were cleared for contesting after scrutiny and who did not withdraw their candidature within the given time are considered as contesting candidate.

[25]. The Sangai Express, English local daily vernacular, Imphal, 20 February 2007

[26]. The Imphal Free Press, English local daily vernacular, 20 February 2007

[27]. Hueiyen News Service, Congress presses ECI to disqualify NPF candidates, The Hueiyenlanpao, Manipur, 8 February 2012

[28]. Staff reporter, NSCN-IM 'poll rampage', The Sangai Express, Manipur, 31 January 2012

[29]. Editor, Silent Elections, Imphal Free Press, Manipur, 23 January 2012

[30]. Press Trust of India, PC admits IM hand in poll orgy, Imphal Free Press, Manipur, 2 February 2012

[31]. Editor, Silent Elections, Imphal Free Press, Manipur, 23 January 2012

[32]. Hueiyen News Service, TMC demands re-poll in hill constituencies while BJP wants re-poll in Thoubal AC, The Hueiyenlanpao, Manipur 31 January 2012

[33]. The Imphal Free Press, English local daily vernacular, 20 February 2007

[34]. The Manipur Mail, English local daily vernacular, 21 February 2007

[35]. The Independence Demand Day of the outfit falls on 25 February. His message was widely publicized in the newspapers and audio-visual media.

[36]. The 6th Manipur Assembly Election 1997 had been countermanded in the valley constituency of Lamshang as proscribed RPF/PLA killed its MPP candidate and former cadre, Mr. M. Deven. The RPF also afterwards killed its former supremo, Mr. Bisheswar who got elected as MLA while in prison.

[37]. Shola Omotola, J., Political Parties and the Quest for Political Stability in Nigeria, Taiwan Journal of Democracy, Volume 6, No. 2, December, 2010. pp. 125-145 